\title{
RASIO KEUANGAN DAN PENGARUHNYA TERHADAP PROFITABILITAS PADA BANK PEMBIAYAAN RAKYAT SYARIAH DI INDONESIA
}

\author{
Syawal Harianto \\ Politeknik Negeri Lhokseumawe \\ syawalpnl@gmail.com
}

\begin{abstract}
Islamic rural banks same like as usual Islamic commercial banks that profit oriented. The aim of this research is to examine the factors that influenc the profitability in Islamic rural banks. The methods that used in this research is multiple regression. The result shows that only efficiency operational ratio (BOPO) and non-performing finance (NPF) that had impact on profitability. The profitability measured by return on asset (ROA). Otherwise, financing to deposit ratio (FDR) and capital adequacy ratio (CAR) doesn't had an impact on Islamic rural bank's profitability. This research implies that Islamic rural banks should increase the operational efficiency and reduce the non-performing finance.
\end{abstract}

Keywords: profitability, Islamic rural bank, multiple regression

\begin{abstract}
Abstrak
Bank pembiayaan rakyat syariah serupa dengan bank komersial lainnya yang berorientasi pada keuntungan. Tujuan dari penelitian ini ialah untuk menguji faktor-faktor yang berpengaruh terhadap bank pembiayaan rakyat syariah. Metode yang dipergunakan dalam penelitian ini ialah regresi berganda. Hasil penelitian menunjukkan bahwa hanya rasio efisiensi operasional (BOPO) dan rasio kredit bermasalah (NPF) berpengaruh terhadap tingkat profitabilitas. Tingkat profitabilitas diukur dengan tingkat pengembalian aset (ROA). Sedangkan rasio pembiayaan terhadap dana pihak ketiga (FDR) dan rasio kecukupan modal (CAR) tidak berpengaruh terhadap bank pembiayaan rakyat syariah. Hasil ini berimplikasi bahwa bank pembiayaan rakyat syariah sebaiknya meningkatkan efisiensi operasional dan menurunkan tingkat pembiayaan bermasalah.
\end{abstract}

Kata Kunci: profitabilita, bank pembiayaan rakyat syariah, regresi berganda

Diterima: 01 November 2016; Direvisi: 28 Januari 2017; Disetujui: 15 Februari 2017 


\section{PENDAHULUAN}

Pertumbuhan bisnis perbankan syariah lebih tinggi jika dibandingkan dengan pertumbuhan perbankan konvensional secara global ditengah kondisi perekonomian yang masih dalam tahap pemulihan, membuktikan perbankan syariah nasional mampu mempertahankan eksistensi dan perkembangannya dalam menghadapi situasi perekonomian, walaupun memiliki tantangan dari segi sumber daya manusia (SDM), produk, jaringan dan permodalan jika dibandingkan perbankan konvensional maupun perbankan syariah global. Akhir tahun 2014, total asset perbankan syariah diperkirakan Rp. 255,2 triliun (pesimis), Rp283,6 triliun (moderat) dan maksimal Rp312 triliun (optimis) sementara total dana pihak ketiga (DPK) diperkirakan di kisaran Rp209,6 triliun (pesimis), Rp220,7 triliun (moderat) dan Rp232,8 triliun (optimis) dan, total pembiayaan akan mencapai minimal Rp216,7 triliun (pesimis), Rp228 triliun (moderat) dan maksimal Rp239,5 triliun (optimis). Berdasarkan tiga skenario tersebut, pangsa pasar perbankan syariah pada akhir tahun 2014 diperkirakan antara 5,25\%-6,25\%.

Rivai, dkk (2013) mengemukakan bahwa Sistem Perbankan syariah telah membuktikan dirinya sebagai suatu sistem yang tangguh melalui krisis ekonomi di Indonesia. Banyak keunggulan yang dimilikinya sehingga dapat bertahan menghadapi keadaan yang sangat sulit bagi dunia Perbankan. Di antara keunggulannya adalah pertumbuhan Perbankan yang terkait dengan pertumbuhan ekonomi riil, sehingga dalam kondisi krisis ekonomi pada tahun 1998 yang dimana Bank konvensional menderita negative spread, dan justru dalam kondisi demikian Bank Umum Syariah menunjukkan kondisi sebaliknya

Perkembangan di dunia perbankan yang sangat pesat serta tingkat kompleksitas yang tinggi, dapat berpengaruh terhadap performa suatu bank. Kompleksitas usaha perbankan yang tinggi dapat meningkatkan risiko yang dihadapi oleh bank-bank yang ada di Indonesia. Lemahnya kondisi bank seperti manajemen yang kurang memadai, pemberian kredit kepada kelompok atau grup usaha sendiri serta modal yang tidak dapat mengcover terhadap risiko-risiko yang dihadapi oleh bank tersebut menyebabkan kinerja bank menurun. Penurunan kinerja bank dapat menurunkan pula kepercayaan masyarakat. 
Profitabilitas dapat dikatakan sebagai salah satu indikator yang paling tepat untuk mengukur kinerja suatu perusahaan. Rasio yang biasa digunakan untuk mengukur kinerja profitabilitas atau rentabilitas adalah Return On Equity (ROE) dan Return On Asset (ROA). Alasan dipilihnya Return On Asset (ROA) sebagai ukuran kinerja adalah karena ROA digunakan untuk mengukur kemampuan manajemen bank dalam memperoleh keuntungan secara keseluruhan. Baskoro (2014) mengemukakan hasil bahwa Return On Asset (ROA) yaitu rasio yang mengukur kemampuan Bank di dalam memperoleh laba dan efisiensi secara keseluruhan, rasio ini terbukti signifikan Dendawijaya (2003) menambahkan semakin besar ROA bank, semakin besar pula tingkat keuntungan yang dicapai bank tersebut dan semakin baik pula posisi bank tersebut dan segi penggunaan aset. Mawaddah (2015) menemukan bahwa pembiayaan dan tingkat marjin bunga bersih (NIM) berpengaruh langsung terhadap tingkat profitabilitas. Sultoni (2014) melakukan penelitian yang berupaya melihat dampak variabel eksternal terhadap tingkat profitabilitas di bank syariah.

Penelitian ini akan menganalisis rasio keuangan di dalam laporan keuangan Bank yang merupakan informasi yang penting dan akurat untuk menganalisis faktor-faktor yang berpengaruh terhadap tingkat profitabilitas di bank pembiayaan rakyat syariah. Rasio keuangan yang akan digunakan oleh penelitian ini adalah: rasio $\mathrm{BOPO}$, rasio NPF, rasio FDR, dan rasio CAR.

\section{METODE}

Teknik analisis yang dipergunakan untuk menjawab tujuan penelitian yaitu menganalisis pengaruh antara BOPO, NPF, FDR, dan CAR terhadap ROA Bank Pembiayan Rakyat Syariah (BPRS) di Indonesia ialah teknik regresi berganda. Data yang digunakan adalah data kuantitatif, yaitu data yang diukur dalam suatu skala numerik (angka).

Adapun persamaan matematis yang dipergunakan dalam penelitian ini:

$$
\mathrm{ROA}_{t}=\alpha+\beta_{1} \mathrm{BOPO}_{t}+\beta_{2} \mathrm{NPF}_{t}+\beta_{3} \text { FDR }_{t}+\beta_{4} \mathrm{CAR}_{t}+\varepsilon_{t}
$$

dimana: ROA ialah rasio profitabilitas; BOPO ialah rasio efisiensi operasional; NPF ialah rasio pembiayaan bermasalah; FDR ialah rasio pembiayaan terhadap dana 
pihak ketiga; CAR ialah rasio kecukupan modal.

\section{HASIL DAN PEMBAHASAN}

\section{Hasil}

Hasil empiris pada Tabel 1 menunjukkan bahwa variabel yang berpengaruh terhadap tingkat profitabilitas pada bank pembiayaan rakyat syariah ialah rasio efisiensi operasional (BOPO) dan rasio pembiayaan bermasalah (NPF). Sedangkan rasio pembiayaan terhadap dana pihak ketiga (FDR) dan rasio kecukupan modal (CAR) tidak berpengaruh terhadap tingkat profitabilitas.

Berdasarkan hasil empiris pada Tabel 1 maka dapat diperoleh model regresi linier berganda sebagai berikut :

$$
\mathrm{ROA}=4,046-0.604 \mathrm{BOPO}-0.180 \mathrm{NPF}+0.052 \mathrm{FDR}+0.041 \mathrm{CAR}
$$

Berdasarkan model regresi di atas dapat dijelaskan bahwa nilai $\alpha$ sebesar 4,046 menunjukkan bahwa jika variabel bebas dalam penelitian ini sama dengan nol maka besarnya Return On Asset akan konstan yaitu sebesar 4,046 satuan. Nilai $\beta_{1}$ sebesar -0.604 menunjukkan bahwa setiap penambahan satuan BOPO sementara NPF, FDR dan ROE tidak mengalami perubahan (tetap) maka ROA akan mengalami penurunan sebesar 0.604 satuan. Hal ini berarti hubungan antara BOPO dan ROA menunjukkan hubungan yang tidak searah (negatif) artinya setiap kenaikan BOPO akan diikuti oleh penuruan Return On Asset. Sebaliknya setiap penurunan BOPO akan mengakibatkan kenaikan Return On Asset.

Tabel 1. Analisis Regresi Linear Berganda

\begin{tabular}{|c|c|c|c|c|c|c|}
\hline \multirow{2}{*}{\multicolumn{2}{|c|}{ Model }} & \multicolumn{2}{|c|}{$\begin{array}{l}\text { Unstandardized } \\
\text { Coefficients }\end{array}$} & \multirow{2}{*}{$\begin{array}{c}\text { Standardized } \\
\text { Coefficients } \\
\text { Beta }\end{array}$} & \multirow[b]{2}{*}{$\mathrm{t}$} & \multirow[b]{2}{*}{ Sig. } \\
\hline & & B & Std. Error & & & \\
\hline \multirow[t]{5}{*}{1} & $\begin{array}{l}\text { (Constant } \\
\text { ) }\end{array}$ & 4.046 & 1.598 & & 2.531 & 0.014 \\
\hline & ВOPO & -0.604 & 0.087 & -0.715 & -6.922 & 0.000 \\
\hline & NPF & -0.180 & 0.084 & -.254 & -2.133 & 0.037 \\
\hline & FDR & 0.052 & 0.277 & 0.018 & 0.188 & 0.852 \\
\hline & CAR & 0.041 & 0.022 & 0.234 & 1.870 & 0.067 \\
\hline
\end{tabular}

a. Dependent Variable: ROA 
Nilai $\beta_{2}$ sebesar -0.180 menunjukkan bahwa setiap penambahan satuan NPF sementara, BOPO, FDR dan CAR tidak mengalami perubahan (tetap) maka Return On Asset akan mengalami penurunan sebesar -0.180 satuan. Hal ini berarti hubungan antara NPF dan ROA menunjukkan hubungan yang tidak searah (negatif) artinya setiap kenaikan NPF akan diikuti oleh penurunan ROA. Nilai $\beta_{3}$ sebesar 0.052 menunjukkan bahwa setiap penambahan satuan FDR sementara BOPO, NPF dan CAR tidak mengalami perubahan (tetap) maka ROA akan mengalami kenaikan sebesar 0.052 satuan. Hal ini berarti hubungan antara FDR dan ROA menunjukkan hubungan yang searah (positif) artinya setiap kenaikan FDR akan diikuti oleh kenaikan ROA. Sebaliknya setiap penurunan FDR akan mengakibatkan penurunan ROA. Nilai $\beta_{4}$ sebesar 0.041 menunjukkan bahwa setiap penambahan satuan CAR sementara BOPO, NPF, dan FDR tidak mengalami perubahan (tetap) maka ROA akan mengalami peningkatan sebesar 0.041 satuan. Hal ini berarti hubungan antara CAR dan ROA menunjukkan hubungan yang tsearah (positif) artinya setiap kenaikan CAR akan diikuti oleh peningkatan ROA. Sebaliknya setiap penurunan CAR akan mengakibatkan penurunan ROA.

Dalam uji F satu sisi dengan $(\alpha 0,05)$ ditemukan bahwa nilai dari $F$ tabel adalah $(2,53)$ diperoleh dari tabel $F$ dengan $n=60, k=4$, sedangkan nilai $F$ hitung sebesar 18.286 dengan begitu maka Fhitung < Ftabel dapat dikatakan bahwa keempat variabel independen secara bersama-sama tidak berpengaruh signifikan terhadap variabel dependennya, sehingga dapat disimpulkan bahwa variabel BOPO, NPF, FDR, dan CAR secara bersama-sama tidak berpengaruh signifikan terhadap ROA. Hasil pengujian F dapat dilihat pada Tabel 2.

Tabel 2. Hasil Uji F

\begin{tabular}{llcrrrr}
\hline Model & & $\begin{array}{c}\text { Sum of } \\
\text { Squares }\end{array}$ & Df & Square & F & \multicolumn{1}{c}{ Sig. } \\
\hline 1 & Regression & 20.887 & 4 & 5.222 & 18.286 & 0.000 \\
& & & & & & a \\
& Residual & 15.705 & 55 & 0.286 & & \\
Total & 36.592 & 59 & & & \\
\hline
\end{tabular}

a. Predictors: (Constant), BOPO, NPF, FDR, CAR

b. Dependent Variable: ROA 
Selanjutnya akan dilihat nilai koefisien determinasi pada penelitian ini. Berdasarkan hasil empiris, menunjukkan nilai adjusted $R^{2}$ sebesar 0.571 . Hal ini menunjukkan bahwa 57,1\% variabel Return On Asset (ROA) dapat dijelaskan oleh keempat variabel independen yaitu BOPO, NPF, FDR, dan CAR. Sedangkan sisanya sebesar $42,9 \%$ dijelaskan oleh faktor lain di luar model.

\section{Pembahasan}

BOPO atau Operational Efficiency Ratio merupakan perbandingan antara total biaya operasi dengan total pendapatan operasi. Rasio ini digunakan untuk mengukur tingkat efisiensi dan kemampuan bank dalam melakukan kegiatan operasinya (Dendawijaya, 2003). Tanda koefisien yang bernilai negatif menunjukkan bahwa semakin tinggi rasio BOPO (semakin kurang efisien bank pembiayaan rakyat syariah), maka tingkat profitabilitas akan menurun. Hasil ini serupa dengan Abdullah (2014); Amelia (2015), dimana rasio BOPO berpengaruh terhadap tingkat profitabilitas di bank syariah.

Rasio Non Performing Financing analog dengan Non Performing Loan pada bank konvensional. Karena pada bank syariah tidak mengenal adanya pinjaman namun menggunakan istilah pembiayaan. NPL mencerminkan risiko kredit, semakin kecil NPL semakin kecil pula risiko kredit yang ditanggung pihak bank (Nusantara, 2009). Hasil ini berbeda dengan Abdullah (2014); Amelia (2015) yang menemukan bahwa rasio pembiayaan bermasalah (NPF) tidak berpengaruh terhadap tingkat profitabilitas di bank syariah.

Hasil penelitian ini menunjukkan bahwa rasio kecukupan modal (CAR) tidak berpengaruh terhadap rasio profitabilitas. Rasio keuangan CAR yang digunakan untuk memprediksi kebangkrutan. Hasil ini serupa dengan Abdullah (2014); Amelia (2015) yang menemukan bahwa rasio CAR tidak berpengaruh terhadap tingkat profitabilitas di bank umum syariah. Namun hasil ini berbeda dengan Yunita (2014) yang menunjukkan bahwa rasio CAR berpengaruh positif terhadap tingkat profitabilitas. Kurniasari (2013) mengemukakan bahwa rasio CAR yang terlalu rendah memungkinkan investasi pada aktiva berisiko tidak dapat ditutup dengan modal sendiri Bank. Ismawati (2015) mengemukakan bahwa Capital Adequacy Ratio (CAR) berpengaruh tidak signifikan terhadap probabilitas Financial 
distress Perbankan dan mempunyai koefisien positif 0,166 yang artinya semakin tinggi rasio CAR kemungkinan Bank mengalami kondisi bermasalah akan semakin kecil.

Hasil penelitian menunjukkan bahwa rasio FDR tidak berpengaruh terhadap tingkat profitabilitas di bank pembiayaan rakyat syariah. Hasil ini serupa dengan Abdullah (2014); Amelia (2015) yang menemukan bahwa rasio FDR tidak berpengaruh terhadap tingkat profitabilitas di bank umum syariah. Namun Yunita (2014) menemukan bahwa rasio FDR berpengaruh positif terhadap tingkat profitabilitas (ROA) di bank umum syariah. Financing to Deposit Ratio (FDR) analog dengan Loan to Deposit Ratio (LDR) pada bank konvensional, merupakan rasio yang digunakan untuk mengukur tingkat likuiditas bank yang menunjukkan kemampuan bank untuk memenuhi permintaan kredit dengan menggunakan total aset yang dimiliki bank (Dendawijaya, 2003).

\section{SIMPULAN}

Penelitian ini menunjukkan bahwa hanya tingkat efisiensi operasional (BOPO) dan tingkat pembiayaan bermasalah (NPF) yang berpengaruh terhadap tingkat profitabilitas di bank pembiayaan rakyat syariah. Sedangkan dua variabel lainnya yaitu rasio FDR dan rasio CAR tidak berpengaruh terhadap tingkat profitabilitas. Hasil ini berimplikasi bahwa bank pembiayaan rakyat syariah harus meningkatkan efisiensi dan menurunkan pembiayaan bermasalah. Oleh karenanya bank pembiayaan rakyat syariah harus lebih berhati-hati dalam melaksanakan operasional perbankannya. Selain itu nilai koefisien determinasi yang tidak terlalu besar menunjukkan bahwa masih banyak faktor di luar model yang ada harus dimasukkan. Hal ini agar benar-benar dapat diketahui faktor-faktor yang mempengaruhi tingkat profitabilitas di bank pembiayaan rakyat syariah.

Keterbatasan dalam penelitian ini hanya menggunakan data publikasi Bank Pembiayaan Rakyat Syariah (BPRS) dari kurun waktu 2010-2015. Selain itu variabel yang digunakan terbatas pada rasio utama dan rasio penunjang Bank Umum Syariah sesuai PBI No. 9/1/PBI/2007 tentang Sistem Penilaian Tingkat Kesehatan Bank Umum Berdasarkan Prinsip Syariah. 


\section{PUSTAKA ACUAN}

Abdullah, M.R. (2014). Determinan Profitabilitas Perbankan Syariah di Indonesia Pasca Krisis Keuangan Global. Jurnal Muamalah. Vol. IV, No. 2: 83-90.

Amelia, E. (2015). Financial Ratio and Its Influence to Profitability in Islamic Banks. Al-Iqtishad: Jurnal Ilmu Ekonomi Syariah (Journal of Islamic Economics). Vol. 7 (2): 229-240.

Dendawijaya, L. (2003). Manajemen Perbankan. Jakarta: PT Ghalia Indonesia

Ismawati, K. \& P.C. Istria. (2015). Detektor Financial distress Perusahaan Perbankan Indonesia. Jurnal Ekonomi Bisnis dan Kewirausahaan, Vol. 4. No 1: 6-29.

Kurniasari, C. \& I. Ghozali. (2013). Analisis Pengaruh Rasio Camel Dalam Memprediksi Financial Distress Perbankan Indonesia Periode 2009-2012. Diponegoro Journal Of Accounting. Vol. 2. No 3: 1-10.

Mawaddah, N. (2015). Faktor-faktor yang Mempengaruhi Profitabilitas Bank Syariah. Etikonomi. Vol. 14 (2): 241-256.

Nusantara, A.B. (2009). Analisis Pengaruh NPL, CAR, LDR, dan BOPO terhadap Profitabilitas Bank (Perbandingan Bank Umum Go Publik dan Bank Umum Non Go Publik di Indonesia Periode Tahun 2005-2007). (Tesis Tidak Dipublikasikan). Semarang: Universitas Diponegoro.

Rivai, V. dkk. (2013). Commercial Bank Management: Manajemen Perbankan dari Teori ke Praktik. Jakarta: Rajawali Pers.

Sultoni, H. (2014). Faktor-faktor Penentu Tingkat Profitabilitas Bank Umum Syariah di Indonesia. Eksyar. Vol 1 (1): 42-55.

Yunita, R. (2014). Faktor-faktor yang Mempengaruhi Tingkat Profitabilitas Perbankan Syariah di Indonesia (Studi Kasus Pada Bank Umum Syariah di Indonesia Tahun 2009-2012). Jurnal Akuntansi Indonesia. Vol. 3 (2): 143160. 